\title{
EFEKTIVITAS SELF-MANAGEMENT PROGRAM TERHADAP MANAJEMEN DIRI KLIEN HIPERTENSI
}

\author{
Sri Wahyuni Adriani' ${ }^{1)}$, Rahmah Naufal Bafadhal ${ }^{2)}$, Mahudeh $^{3)}$ \\ Fakultas Ilmu Kesehatan, Universitas Muhammadiyah Jember, Jember, Indonesia \\ email: sriwahyuni@unmuhjember.ac.id
}

\begin{abstract}
Abstrak
Manajemen diri penting dilakukan oleh klien hipertensi untuk meningkatkan keberhasilan dalam mengatasi hipertensi. Tujuan penelitian ini untuk mengetahui efektivitas self-management program terhadap manajemen diri klien hiprtensi. Penelitian ini merupakan penelitian eksperimen dengan desain randomised control trial (RCT).Penelitian ini telah dilakukan di wilayah kerja Dinas Kesehatan Kabupaten Jember. Populasi dalam penelitian ini adalah penderita hipertensi sejumlah kurang lebih 119, dengan sampel yang terpilih menggunakan cluster random sampling yaitu 35 kelompok intervensi dan 35 kelompok kontrol. Analisis data menggunakan uji Mann-Whitney U Test dan independent t-test. Hasil penelitian menunjukkan ada perbedaan yang signifikan antara kelompok intervensi dan kelompok kontrol tentang manajemen diri meliputi integrasi diri, regulasi diri, interaksi dengan tenaga kesehatan dan lainnya, pemantauan tekanan darah, serta kepatuhan terhadap aturan yang dianjurkan. Kelompok intervensi mempunyai skor manajemen diri yang lebih tinggi dibandingkan dengan kelompok kontrol. Selain itu juga ada perbedaan yang siginifikan tekanan darah sistolik dan diastolik antara kelompok kontrol dan kelompok intervensi. Tekanan darah sistolik dan diastolik kelompok intervensi menurun atau lebih rendah dibandingkan dengan tekanan darah sistolik dan diastolik kelompok kontrol.Self-management program efektif dalam meningkatkan manajemen diri klien hipertensi.
\end{abstract}

Kata kunci: hipertensi, manajemen diri,self-management program

\begin{abstract}
Self-management is important for hypertension clients to improve hypertension management. The purpose of this study was to determine the effectiveness of self-management programs on the self-management of hypertensive clients. This research is an experimental study with a randomized control trial (RCT) design. This research has been conducted in the working area of the Jember District Health Office. The population in this study was 119 hypertension patients, with a sample selected used cluster random sampling (35 intervention groups and 35 control groups). The results showed that there were significant differences between the intervention group and the control group regarding self-management including self-integration, self-regulation, interactions with health workers and others, monitoring blood pressure, and adherence to recommended rules. The intervention group had a higher self-management score than the control group. In addition, there was also a significant difference in systolic and diastolic blood pressure between the control group and the intervention group. The systolic and diastolic blood pressure in the intervention group is lower than the systolic and diastolic blood pressure in the control group. A self-management program is effective in improving self-management of hypertensive clients.
\end{abstract}

Keywords: hypertension, self-management, self-management program

\section{PENDAHULUAN}

Hipertensi hingga saat ini masih menjadi masalah kesehatan utama di dunia. Hasil survei yang dilakukan World Health Organization (WHO) melaporkan bahwa angka kejadian hipertensi mengalami peningkatan yang signifikan setiap tahunnya. Tahun 2010 hampir 7.5 juta orang meninggal karena penyakit hipertensi dan komplikasinya atau berkontribusi sekitar $12.5 \%$ dari total kematian di dunia. Sedangkan pada tahun 2013 WHO melaporkan terdapat 1.5 miliar orang di dunia menderita hipertensi pada usia diatas 20 tahun (WHO, 2013). Lebih lanjut, WHO memproyeksikan bahwa pada tahun 2025 akan ada sekitar $29 \%$ populasi dewasa di dunia terkena hipertensi (Guzman, 2012).

Kondisi yang sama juga terjadi di Indonesia. Prevalensi hipertensi pada kelompok usia di atas 18 tahun terus mengalami peningkatan. Tahun 2013 
prevalensi hipertensi sebesar 25.8\% meningkat menjadi $34.1 \%$ di tahun 2018 atau terjadi peningkatan sebesar $8.3 \%$ selama 5 tahun dan diperkirakan setiap tahunnya meningkat sebesar 3\%. Prevalensi hipertensi tertinggi terjadi di Kalimantan Selatan (44.1\%), Jawa Barat (29.6\%), dan Kalimantan Timur (29.4\%). Sedangkan Jawa Timur menempati peringkat kelima dengan prevalensi hipertensi sebesar 22.71\% (Badan Penelitian dan Pengembangan Kesehatan Kemenkes RI, 2018).

Berdasarkan Profil Kesehatan Provinsi Jawa Timur Tahun 2018, persentase hipertensi di Provinsi Jawa Timur sekitar 2.360 .592 penduduk, dengan proporsi laki-laki sebesar $18.99 \%$ (808.009 penduduk) dan perempuan sebesar $18.76 \%$ (1.146.412 penduduk) (Dinas Kesehatan Provinsi Jawa Timur, 2018). Kabupaten Jember turut menyumbang angka tingginya prevalensi hipertensi di Jawa Timur. Berdasarkan data dari Dinas Kesehatan Kabupaten Jember tahun 2018, jumlah kasus hipertensi dari tahun 2014-2017 memiliki jumlah kasus terbanyak pada penyakit tidak menular dan menjadi prioritas utama untuk ditangani. Data penyakit hipertensi memiliki jumlah 22.185 kasus pada 2014 kemudian meningkat menjadi 29.683 kasus di tahun 2015. Penurunan kasus terjadi di tahun 2016 sejumlah 28.403 kasus dan meningkat kembali menjadi 30.511 kasus pada 2017 (Dinas Kesehatan Kabupaten Jember, 2018).

Tingginya angka kejadian hipertensi akan mempengaruhi derajat kesehatan masyarakat. Hipertensi memberikan dampak negatif terhadap fisik, psikologis, ekonomi dan sosial. Hipertensi memiliki dampak yang signifikan pada peningkatan risiko penyakit kronis dan dinyatakan bahwa hipertensi meningkatkan risiko infark miocard, penyakit ginjal, stroke dan gagal jantung (Kabakci et al., 2010). Hipertensi persisten dapat mengarah pada kondisi gagal ginjal terminal atau End Stage Renal Failure (ESRF) dimana 80-90\% pasien diharuskan menjalani cuci darah. Hipertensi merupakan faktor risiko utama untuk terjadinya masalah kesehatan seperti stroke, infark miokard, gagal jantung, aneurisma arteri, penyakit arteri perifer dan penyakit ginjal kronik (Black, J.M \& Hawks, 2014). Penelitian menyatakan masalah lain yang terjadi pada pasien hipertensi diantaranya gangguan tidur, kesehatan yang buruk, ketidakstabilan mood, tidak bahagia dan harga diri rendah (Salman, R.A, Al-Rubeaan, 2009).

Meskipun pencegahan dan penanganan hipertensi dilaporkan menjadi isu kesehatan masyarakat yang sangat penting, menyusun strategi yang tepat untuk menekan laju hipertensi masih menjadi permasalahan dunia (Chen Y, Factor-Litvak P , Howe GR , Parvez F, 2006). Hasil survei di beberapa negara di dunia menemukan bahwa kesadaran masyarakat masih rendah mengenai pentingnya kontrol tekanan darah (Chokalingam, 2008). Meskipun telah banyak tindakan untuk mengontrol hipertensi, dilaporkan bahwa di negara berkembang maupun negara maju seperti Amerika Serikat, hanya sepertiga pasien hipertensi yang mengontrol tekanan darahnya (Bosworth $\mathrm{HB}$, Olsen MK, Dudley T, Orr M, Neary A, Harrelson M, Adams M, Svetkey LP, Dolor RJ, 2007). Di Indonesia, upaya untuk menangani hipertensi diantaranya melalui program Gerakan Masyarakat Sehat (GERMAS). Namun program tersebut juga belum mampu menekan laju hipertensi. Diketahui bahwa salah satu faktor yang mempengaruhinya yaitu rendahnya pengetahuan yang berhubungan dengan manajemen diri (self management) mengenai kepatuhan minum obat dan modifikasi gaya hidup seperti diit dan latihan. Rendahnya manajemen diri penderita hipertensi adalah penyebab terbesar meningkatnya mortalitas dan morbiditas penderita hipertensi (Black, J.M \& Hawks, 2014).

Self management merupakan perawatan diri yang dilakukan secara mandiri oleh pasien seperti kontrol tekanan darah, mencegah komplikasi, dan memperbaiki kualitas hidupnya (Lin et al., 2008). Modifikasi diet, perubahan gaya hidup, mengkonsumsi obat antihipertensi secara teratur, dan kontrol tekanan darah secara rutin merupakan aspek penting dalam self management. Konsumsi obat secara teratur dapat membantu memperbaiki kondisi penyakit dan mencegah komplikasi hipertensi. Manajemen diri dibutuhkan oleh penderita hipertensi untuk membuat mereka sehat dengan melakukan latihan, menurunkan berat badan bagi yang berat badannya berlebih, dan mengubah kebiasaan makan sehingga mereka dapat mengontrol tekanan darah secara efektif.

Menurut Wagner's Chronic Care Model, kontrol terhadap penyakit kronis membutuhkan partisipasi aktif dari pasien itu sendiri dan petugas kesehatan. Interaksi yang baik antara pasien dan petugas kesehatan menunjukkan hasil positif yang signifikan dalam meningkatkan kontrol penyakit. Petugas kesehatan memberikan pendampingan terhadap pasien untuk mengontrol penyakitnya dengan memberikan bantuan terhadap mereka beserta keluarga; meningkatkan pengetahuan dan keterampilan terhadap perawatan penyakit; mengembangkan efikasi diri dan dukungan sosial untuk mendiskusikan kesulitan yang dialami dalam pengobatan dan meningkatkan motivasi dalam melakukan perawatan terhadap penyakit. Dengan demikian self-management program merupakan salah satu intervensi yang penting dilakukan oleh petugas kesehatan sebagai bentuk pendekatan untuk meningkatkan perawatan diri penderita hipertensi. 
Tujuan penelitian ini adalah menganalisis efektifitas self-management program terhadap manajemen diri klien hipertensi.

\section{METODE PENELITIAN}

Penelitian ini merupakan penelitian eksperimen dengan desain randomised control trial (RCT). Populasi dalam penelitian ini adalah penderita hipertensi sejumlah kurang lebih 119 berdasarkan rerata angka kunjungan dalam 3 bulan terakhir. Metode sampling yang digunakan adalah cluster random sampling. Sampel diambil dengan melakukan kunjungan rumah terhadap klien yang mengalami hipertensi yang memenuhi kriteria inklusi yaitu : Didiagnosis hipertensi paling tidak selama 6 bulan; Usia > 18 tahun; memiliki kesadaran penuh; Mampu berkomunikasi dengan baik. Rencana proses pengambilan sampel tampak pada Gambar 1 .

Instrumen penelitian diadopsi dari penelitian Lin et al. (2008) yang dimodifikasi oleh peneliti sesuai bahasa dan kondisi di tempat penelitian. Instrumen yang digunakan terdiri dari 3 bagian yaitu: 1) Data demografi; 2) Data pengkajian status kesehatan; 3) Hypertension Self-Management Behaviour Questionnaire (HSMBQ). Kuesioner data demografi terdiri dari usia, tingkat pendidikan, jenis kelamin, status perkawinan, pekerjaan, pendapatan per bulan, dan jumlah anggota keluarga. Kuesioner pengkajian status kesehatan meliputi tekanan darah, berat badan, tinggi badan, IMT, kapan didiagnosis hipertensi, riwayat merokok, kebiasaan konsumsi alkohol, dan penyakit penyerta (co-morbid). Hypertension Self-Management Behaviour Questionnaire (HSMBQ) dimodifikasi oleh peneliti dari Diabetes Self-Management Instrument yang dikembangkan oleh Lin, et al. (2008). HSMBQ terdiri dari 40 item pertanyaan yang berkaitan dengan manajemen diri untuk penanganan penyakit. Terdapat 5 aspek yang dinilai yaitu integrasi diri (13 item), regulasi diri (9 item), interaksi dengan petugas kesehatan dan orang yang berpengaruh (9 item), monitoring diri (4 item) dan kepatuhan regimen terapi (5 item). Tiap item terdiri dari 4 pilihan jawaban dengan rentang nilai dari 1 (tidak pernah) sampai 4 (selalu). Skor manajemen diri dikategorikan menjadi 3 level yaitu rendah, cukup, dan tinggi. Rerata atau nilai mean 1.00-2.00 berarti manajemen diri rendah, skor 2.01-3.00 berarti manajemen diri cukup, dan skor 3.01-4.00 berarti manajemen diri baik.

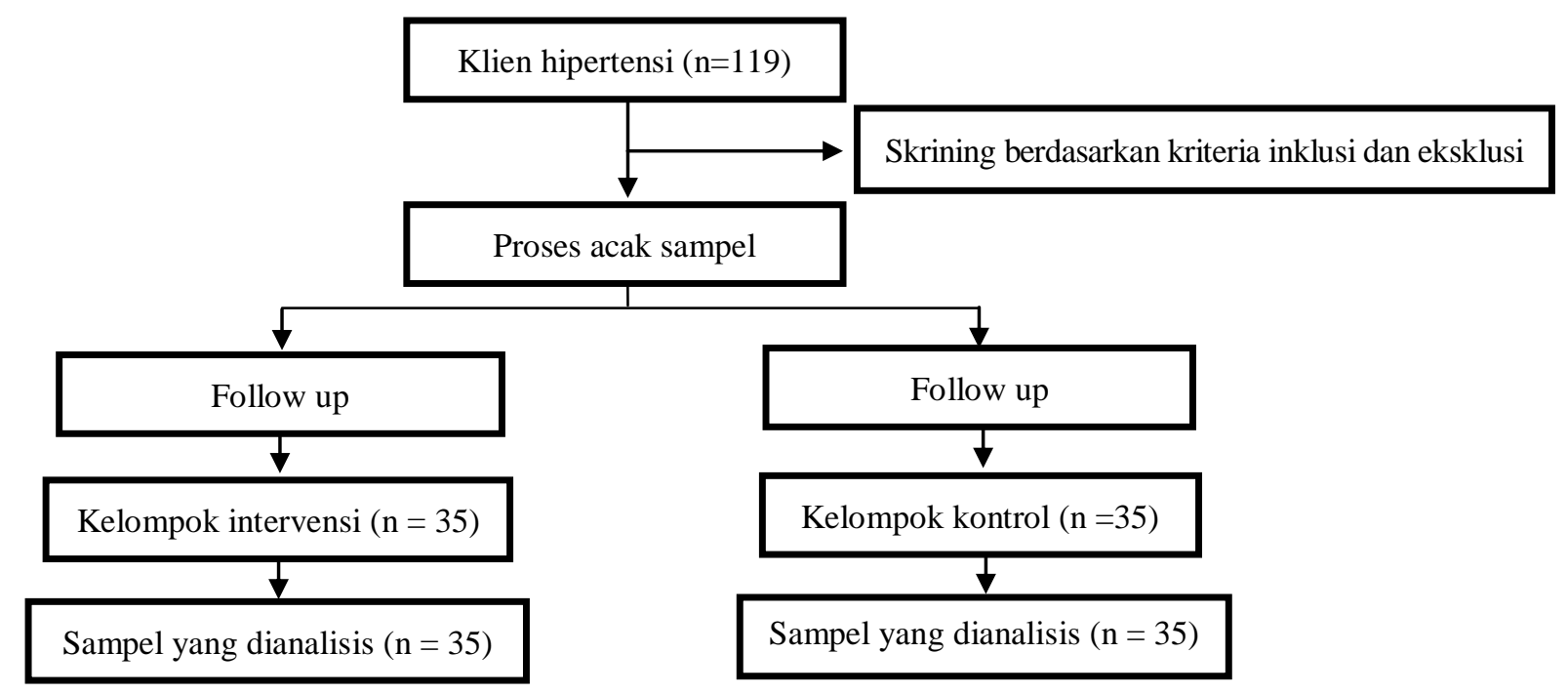

Gambar 1. Proses Pemilihan Sampel

\section{HASIL DAN PEMBAHASAN}

Karakeristik responden hampir sama antara kelompok intervensi dan kelompok kontrol. Dari karaktersitik usia diketahui hampir setengah usia responden berada dalam rentang usia 46-55 tahun, sebagian besar berjenis kelamin perempuan, status kawin, tingkat pendidikan hampir setengahnya berpendidikan SD, pekerjaan hampir setengahnya adalah ibu rumah tangga, pendapatan hampir setengahnya berada dalam kisaran 1.000.0002.300.000, jumlah anggota keluarga rata-rata 4-6 orang, lama didiagnosis hipertensi berkisar 1-5 tahun, sebagian besar tidak mempunyai riwayat merokok dan tidak mengkonsumsi alkohol, mayoritas tidak mempunyai penyakit penyerta, kategori hipertensi sebagian besar berada pada kondisi hipertensi stadium 1, dan indeks massa tubuh hampir seluruhnya berada dalam kategori normal (Tabel 1). 
Tabel 1. Karakteristik Responden Kelompok Intervensi dan Kelompok Kontrol

\begin{tabular}{|c|c|c|c|c|c|}
\hline \multirow[t]{2}{*}{ Variabel } & & \multicolumn{2}{|c|}{$\begin{array}{c}\text { Kelompok } \\
\text { Intervensi } \\
(\mathbf{n}=\mathbf{3 5}) \\
\end{array}$} & \multicolumn{2}{|c|}{$\begin{array}{l}\text { Kelompok Kontrol } \\
\quad(\mathbf{n}=\mathbf{3 5})\end{array}$} \\
\hline & & $\mathbf{n}$ & $\begin{array}{c}\text { Persentase } \\
(\%)\end{array}$ & $\mathbf{n}$ & $\begin{array}{c}\text { Persentase } \\
(\%)\end{array}$ \\
\hline \multirow[t]{5}{*}{ Usia } & 26-35 tahun & 6 & 17,14 & 4 & 11,42 \\
\hline & 36-45 tahun & 4 & 11,42 & 5 & 14,29 \\
\hline & 46-55 tahun & 17 & 48,58 & 21 & 60,0 \\
\hline & 56-65 tahun & 5 & 14,29 & 3 & 8,57 \\
\hline & $>65$ tahun & 3 & 8,57 & 2 & 5,72 \\
\hline \multirow[t]{2}{*}{ Jenis kelamin } & Laki-laki & 14 & 40,0 & 15 & 42,86 \\
\hline & Perempuan & 21 & 60,0 & 20 & 57,14 \\
\hline \multirow{3}{*}{$\begin{array}{l}\text { Status } \\
\text { perkawinan }\end{array}$} & Kawin & 25 & 71,43 & 27 & 77,14 \\
\hline & Cerai & 3 & 8,57 & 2 & 5,72 \\
\hline & Janda/duda & 7 & 20,0 & 6 & 17.14 \\
\hline \multirow{5}{*}{$\begin{array}{l}\text { Tingkat } \\
\text { pendidikan }\end{array}$} & Tidak sekolah & 7 & 20,0 & 9 & 25,71 \\
\hline & $\mathrm{SD}$ & 13 & 37,14 & 15 & 42,85 \\
\hline & SMP & 8 & 22,85 & 6 & 17,14 \\
\hline & SMA & 4 & 11,42 & 5 & 14,28 \\
\hline & Perguruan Tinggi & 3 & 8,57 & 0 & 0 \\
\hline \multirow[t]{7}{*}{ Pekerjaan } & Tidak bekerja & 2 & 5,72 & 0 & 0 \\
\hline & PNS & 1 & 2,85 & 0 & 0 \\
\hline & Pedagang & 2 & 5,72 & 4 & 11,42 \\
\hline & Petani & 10 & 28,57 & 9 & 25,71 \\
\hline & Buruh & 2 & 5,72 & 3 & 8,57 \\
\hline & Pegawai swasta & 3 & 8,57 & 6 & 17,14 \\
\hline & Ibu rumah tangga & 15 & 42,85 & 13 & 37,14 \\
\hline \multirow{3}{*}{$\begin{array}{l}\text { Pendapatan per } \\
\text { bulan }\end{array}$} & $<1.000 .000$ & 11 & 31,42 & 9 & 25,72 \\
\hline & $1.000 .000-2.300 .000$ & 17 & 48,58 & 21 & 60,0 \\
\hline & $2.300 .000-5.000 .000$ & 7 & 20,0 & 5 & 14,28 \\
\hline Anggota & $1-3$ orang & 10 & 28,58 & 7 & 20,0 \\
\hline \multirow[t]{2}{*}{ keluarga } & 4-6 orang & 21 & 60,0 & 23 & 65,72 \\
\hline & $>6$ orang & 4 & 11,42 & 5 & 14,28 \\
\hline \multirow[t]{3}{*}{ Lama diagnosis } & 3-12 bulan & 11 & 31,42 & 9 & 25,72 \\
\hline & $1-5$ tahun & 20 & 57,14 & 18 & 51,42 \\
\hline & $>5$ tahun & 4 & 11,42 & 8 & 22,86 \\
\hline Riwayat & Tidak pernah & 19 & 54,28 & 20 & 57,14 \\
\hline \multirow[t]{2}{*}{ merokok } & Pernah, namun sudah berhenti & 3 & 8,57 & 2 & 5,72 \\
\hline & Masih merokok & 13 & 37,15 & 13 & 37,14 \\
\hline Konsumsi & Tidak pernah & 33 & 94,28 & 34 & 97,14 \\
\hline alkohol & $2-4 x /$ bulan & 2 & 5,72 & 1 & 2,86 \\
\hline Penyakit & Tidak ada & 25 & 71,42 & 30 & 85,72 \\
\hline penyerta & Ada & 10 & 28,58 & 5 & 14,28 \\
\hline \multirow[t]{3}{*}{ Tekanan darah } & 120-139/80-89 mmHg (Prehipertensi) & 5 & 14,28 & 3 & 8,57 \\
\hline & 140-159/90-99 mmHg (Hipertensi Stadium 1) & 23 & 65,72 & 24 & 68,57 \\
\hline & $>=160 />=100$ mmHg (Hipertensi Stadium 2) & 7 & 20,0 & 8 & 22,86 \\
\hline massa & $17-18,5$ (Kurus) & 1 & 2,85 & 0 & 0 \\
\hline \multirow[t]{3}{*}{ tubuh } & $18,5-25$ (Normal) & 29 & 82,86 & 30 & 85,72 \\
\hline & $>25-27$ (Gemuk) & 4 & 11,44 & 5 & 14,28 \\
\hline & $>27$ (Obesitas) & 1 & 2,85 & 0 & 0 \\
\hline
\end{tabular}


Berdasarkan Tabel 2 diketahui bahwa sebelum intervensi, tidak ada perbedaan yang signifikan antara kelompok intervensi dan kelompok kontrol tentang manajemen diri meliputi integrasi diri, regulasi diri, interaksi dengan tenaga kesehatan dan lainnya, pemantauan tekanan darah, serta kepatuhan terhadap aturan yang dianjurkan. Namun terdapat perbedaan yang siginifikan antara kelompok kontrol dan kelompok intervensi setelah kelompok intervensi diberikan self-management program selama 4 minggu yang mencakup 5 dimensi manajemen diri. Kelompok intervensi mempunyai skor manajemen diri yang lebih tinggi dibandingkan dengan kelompok kontrol, baik itu tentang integrasi diri, regulasi diri, interaksi dengan tenaga kesehatan dan lainnya, pemantauan tekanan darah, serta kepatuhan terhadap aturan yang dianjurkan. Dengan demikian maka selfmanagement program efektif dalam meningkatkan manajemen diri klien hipertensi.

Tabel 3 menunjukkan bahwa tidak ada perbedaan yang signifikan antara tekanan darah sistolik dan diastolik antara kelompok kontrol dan kelompok intervensi sebelum intervensi selfmanagement program. Namun setelah kelompok intervensi diberikan self-management program terdapat perbedaan yang siginifikan tekanan darah sistolik dan diastolik antara kelompok kontrol dan kelompok intervensi. Tekanan darah sistolik dan diastolik kelompok intervensi menurun atau lebih rendah dibandingkan dengan tekanan darah sistolik dan diastolik kelompok kontrol. Dengan demikian maka self-management program efektif dalam menurunkan tekanan darah pada klien hipertensi.

Tabel 2. Perbandingan Rerata Skor Manajemen Diri antara Kelompok Intervensi dan Kelompok Kontrol

\begin{tabular}{|c|c|c|c|c|c|}
\hline \multicolumn{2}{|l|}{ Variabel } & $\begin{array}{l}\text { Kelompok Intervensi } \\
\quad(\mathbf{n}=\mathbf{3 5})\end{array}$ & $\begin{array}{c}\text { Kelompok Kontrol } \\
(\mathbf{n}=\mathbf{3 5})\end{array}$ & \multirow[t]{2}{*}{$\mathbf{Z}$} & \multirow[t]{2}{*}{$p$} \\
\hline \multirow{3}{*}{ Integrasi diri } & & Mean & Mean & & \\
\hline & Pretest & 42,15 & 43,0 & $-0,156$ & 0,868 \\
\hline & Posttest & 48,95 & 42,50 & $-2,041$ & 0,041 \\
\hline \multirow[t]{2}{*}{ Regulasi diri } & Pretest & 47,99 & 49,05 & $-0,211$ & 0,833 \\
\hline & Posttest & 54,88 & 41,57 & $-2,608$ & 0,009 \\
\hline Interaksi dengan & Pretest & 52,42 & 44,24 & $-1,595$ & 0,111 \\
\hline kesehatan dan lainnya & Posttest & 55,04 & 41,39 & $-2,562$ & 0,010 \\
\hline \multirow[t]{2}{*}{ Pemantauan tekanan darah } & Pretest & 50,86 & 45,93 & $-0,920$ & 0,358 \\
\hline & Posttest & 58,23 & 37,92 & $-3,694$ & 0,001 \\
\hline \multirow{2}{*}{$\begin{array}{l}\text { Kepatuhan terhadap aturan } \\
\text { yang dianjurkan }\end{array}$} & Pretest & 48,74 & 48,24 & $-0,153$ & 0,567 \\
\hline & Posttest & 49,00 & 47,96 & $-1,043$ & 0,011 \\
\hline
\end{tabular}

$\mathrm{Z}=$ Mann - Whitney U test

Tabel 3. Perbandingan Rerata Tekanan Darah antara Kelompok Intervensi dan Kelompok Kontrol

\begin{tabular}{clccccc}
\hline \multirow{2}{*}{ Variabel } & & $\begin{array}{c}\text { Kelompok Intervensi } \\
(\mathbf{n = 3 5})\end{array}$ & $\begin{array}{c}\text { Kelompok Kontrol } \\
(\mathbf{n = 3 5})\end{array}$ & \multirow{2}{*}{$\mathbf{t}$} & \multirow{p}{*}{$\boldsymbol{p}$} \\
\cline { 3 - 4 } & & Mean & Mean & & \\
\hline Tekanan darah sistolik & Pretest & 150,19 & 141,61 & & 0,745 & 0,358 \\
& Posttest & 129,66 & 140,67 & & $-5,499$ & 0,001 \\
Tekanan darah diastolik & Pretest & 80,76 & 79,85 & & 0,538 & 0,492 \\
& Posttest & 72,88 & 78,34 & & $-2,140$ & 0,025 \\
\hline
\end{tabular}

$\mathrm{t}=$ Independent $\mathrm{t}-$ Test

Self-management program efektif dalam meningkatkan manajemen diri klien hipertensi yang mencakup 5 dimensi meliputi integrasi diri, regulasi diri, interaksi dengan tenaga kesehatan dan lainnya, pemantauan tekanan darah, serta kepatuhan terhadap aturan yang dianjurkan. Hasil ini sama dengan penelitian lain yang menemukan bahwa self-management program efektif dalam kemampuan perawatan diri dan tekanan darah (Lestari, Inda Galuh, Isnaini, 2018); (Sagala, 2019) Hasil ini menjelaskan kaitan antara program manajemen diriberdasarkan teori keperawatan self care deficit Orem's dan cognitive-hebavioral therapy (Dolrat Rujiwatthanakorn, Orasa Panpakdee, Porntip Malathum, 2011). Orem menyatakan bahwa sistem keperawatan yang 
edukatif dan mendukung serta bantuan metode melalui tindakan keperawatan yang diberikan pada pasien yang memiliki pengetahuan yang kurang atau keterampilan yang kurang memadai membutuhkan tindakan keperawatan. Klien dalam penelitian ini adalah pasien hipertensi yang membutuhkan bantuan dalam pengambilan keputusan, kontrol perilaku dan dalam meningkatkan pengetahuan serta keterampilan dalam manajemen diri untuk mengatasi penyakitnya. Selain itu, menurut teori cognitivebehavioral therapy menyatakan bahwa seseorang dengan emosi dan perilaku negatif lebih berpengaruh terhadap kemampuan kognitifnya. Dengan demikian maka kondisi ini dapat diubah dengan kognitif dan teknik perilaku, salah satunya program manajemen diri. Temuan ini menyatakan bahwa self-management program membantu klien khususnya kelompok intervensi untuk memahami manajemen diri untuk mengatasi penyakit hipertensi melalui integrasi diri, regulasi diri, interaksi dengan tenaga kesehatan dan lainnya, pemantauan tekanan darah, serta patuh terhadap aturan yang dianjurkan.

Saat melaksanakan self-management program, terdapat beberapa responden kelompok intervensi belum memahami dengan baik tentang manajemen diri hipertensi sehingga kadang mengalami mispersepsi seperti tidak perlu melakukan pengobatan, tidak melakukan diit dan aktivitas fisik yang teratur, dan cenderung mengabaikan penyakitnya. Untuk mengatasi hal tersebut, digunakan metode sharing atau berbagai pengalaman dengan keluarga lain yang mengalami penyakit yang sama, terutama para pasien yang telah mendapatkan dampak buruk hipertensi, para pasien yang telah sukses dengan pengobatan hipertensi diminta untuk berbagi pengalamannya agar memberikan motivasi bagi klien untuk lebih sadar dan peduli terhadap penyakitnya.

Responden penelitian khususnya kelompok intervensi diarahkan untuk mempunyai tujuan jangka pendek dan rencana aktivitas untuk mencapai tujuan tersebut, sehingga mereka difasilitasi untuk menuliskan tujuan tersebut dan langkah apa yang harus dilakukan dalam kegiatan harian mereka. Selain itu untuk memantau aktivitas tersebut, maka dilakukan monitoring atau observasi untuk melihat ketercapaian dari tujuan yang telah ditetapkan. Responden juga berdiskusi dalam melaksanakan kegiatan serta semua hal yang ingin diketahui dipecahkan bersama melalui diskusi dengan para anggota keluarga. Dengan cara ini maka motivasi responden kelompok intervensi menjadi lebih baik dibandingkan kelompok kontrol karena mereka mempunyai keinginan yang kuat melalui tujuan yang ingin dicapai dan prencanaan aktivitas yang jelas.

Self-management program ternyata juga dapat meningkatkan pengetahuan, keterampilan dan motivasi antar sesama klien terutama dalam kelompok intervensi melalui partisipasi aktif dalam manajemen diri, mengidentifikasi permasalahan, menemukan solusi, membuat rencana tindakan, serta mengevaluasi keberhasilan tindakan. Dengan melakukan beberapa aktivitas tersebut, mereka mempunyai pemahaman dan keterampilan lebih baik tentang bagaimana mengatasi penyakitnya dan bagaimana mereka mengubah perilaku secara perlahan untuk mengatasi penyakitnya. Namun demikian program ini membutuhkan motivasi dan dukungan dari semua sumber terutama anggota keluarga dan orang-orang terdekat yang menjadi kepercayaan pasien.

\section{KESIMPULAN DAN SARAN}

Terdapat perbedaan yang siginifikan antara kelompok kontrol dan kelompok intervensi setelah kelompok intervensi diberikan self-management program selama 4 minggu yang mencakup 5 dimensi manajemen diri. Kelompok intervensi mempunyai skor manajemen diri yang lebih tinggi dibandingkan dengan kelompok kontrol. Begitu pula tekanan darah sistolik dan diastolik antara kelompok kontrol dan kelompok intervensi. Tekanan darah sistolik dan diastolik kelompok intervensi menurun atau lebih rendah dibandingkan dengan tekanan darah sistolik dan diastolik kelompok kontrol. Dengan demikan selfmanagement program efektif dalam meningkatkan manajemen diri dan menurunkan tekanan darah pasien hipertensi.

Sebagai ujung tombak pemberi layanan, maka petugas kesehatan disarankan rutin melaksanakan monitoring dan evaluasi serta melakukan pemeriksaan secara berkala melalui kunjungan rumah untuk meningkatkan manajemen diri pasien hipertensi. Intervensi ini dapat diberikan oleh petugas kesehatan dalam meningkatkan keberhasilan manajemen hipertensi.

\section{REFERENSI}

Badan Penelitian dan Pengembangan Kesehatan Kemenkes RI. (2018). Hasil utama RISKESDAS 2018.

Black, J.M \& Hawks, J. . (2014). Medical surgical nursing: Clinical management for positive outcomes (7th ed.). Elsevier Saunder. 
Bosworth HB, Olsen MK, Dudley T, Orr M, Neary A, Harrelson M, Adams M, Svetkey LP, Dolor RJ, O. E. (2007). he Take Control of Your Blood pressure (TCYB) study: study design and methodology. Contemp Clin Trials, 28(1), 3347. https://doi.org/10.1016/j.cct.2006.08.006

Chen Y, Factor-Litvak P , Howe GR, Parvez F, A. H. . (2006). Nutritional influence Nutritional influence on risk of high blood pressure in Bangladesh :June 2014.

Chokalingam, A. (2008). World hypertension day and global awareness. The Canadian Journal of Cardiology, 24(6), 441-444. https://doi.org/10.1016/s0828282x(08)70617-2

Dinas Kesehatan Kabupaten Jember. (2018). Profil kesehatan Kabupaten Jember tahun 2018.

Dinas Kesehatan Provinsi Jawa Timur. (2018). Profil kesehatan provinsi Jawa Timur tahun 2018.

Dolrat Rujiwatthanakorn, Orasa Panpakdee, Porntip Malathum, S. T. (2011). Effectiveness of a Self-Management Program for Thais with Essential Hypertension. Pacific Rim Int J Nurs Res, 15(2), 97-109. https://login.proxy.bib.uottawa.ca/login?url=ht tp://search.ebscohost.com/login.aspx?direct=tr $\mathrm{ue} \& \mathrm{db}=\operatorname{cin} 20 \& \mathrm{AN}=2009193720 \&$ site $=$ ehostlive

Guzman, N. (2012). Epidemiology and management of hypertension in the hispanic population. $A m$ J Cardiovasc Drugs, 12(3), 165-178.
Kabakci, G., Aydin, M., Demir, I., Kirma, C., \& Özerkan, F. (2010). Global cardiometabolic risk profile in patients with hypertension: Results from the Turkish arm of the pan-European GOOD survey. Turk Kardiyoloji Dernegi Arsivi, 38(5), 313-320.

Lestari, Inda Galuh, Isnaini, N. (2018). Pengaruh Self Management Terhadap Tekanan Darah Lansia Yang Mengalami Hipertensi. Indonesian Journal for Health Sciences, 2(1), 7-18. https://doi.org/10.24269/ijhs.v2i1.2018.pp7-18

Lin, C. C., Anderson, R. M., Chang, C. S., Hagerty, B. M., \& Loveland-Cherry, C. J. (2008). Development and testing of the diabetes selfmanagement instrument: A confirmatory analysis. Research in Nursing and Health, 31(4), 370-380. https://doi.org/10.1002/nur.20258

Sagala, L. M. (2019). Pengaruh Hypertention Self Management Education ( Hsme) Terhadap Tekanan Darah Di Puskesmas Kabanjahe. Indonesian Trust Health Journal, 2(1), 121-127. https://doi.org/10.37104/ithj.v2i1.23

Salman, R.A, Al-Rubeaan, K. A. . (2009). Incidence and risk factors of hypertension among Saudi type 2 diabetes adults patients: An 11-year prospective randomized study. Journal of Diabetes and Its Complication, 23(2), 95-101. https://doi.org/https://doi.org/10.1016/j.jdiacomp. 2007.10.004

WHO. (2013). A global brief on hypertension: sillent killer: global public helath crisis. 